\title{
Hick's Theory of Religion and the Traditional Islamic Narrative
}

\author{
Amir Dastmalchian
}

Published online: 18 June 2013

C) Springer Science+Business Media Dordrecht 2013

\begin{abstract}
This article considers the traditional Islamic narrative in the light of the theory of religion espoused by John Hick (1922-2012). We see how the Islamic narrative changes on a Hickean understanding of religion, particularly in the light of the 'bottom-up' approach and trans-personal conception of the religious ultimate that it espouses. Where the two readings of Islam appear to conflict, I suggest how they can be reconciled. I argue that if Hick's theory is incompatible with Islamic belief, then this incompatibility does not manifest itself at the level of belief in the narrative.
\end{abstract}

Keywords Hick, John · Religious diversity $\cdot$ Religious studies $\cdot$ Pluralism · Islam

\section{Introduction}

The general phenomenon of religion has given rise to a number of second order theories that have tried to explain it. But from Durkheim to Dennett, these theories have not sought to be sympathetic to religion but, rather, to construe religion in nonreligious terms. Émile Durkheim's (1858-1917) seminal reflections on religion left him fundamentally connecting religion with a 'moral community' (1915) and for Daniel Dennett (2006) religion is best understood in terms of memes.

John Hick's (2004) contribution to the study of religion has been to propose a theory of religion that is at once sympathetic to the phenomenon of religion yet not committed to any particular instantiation of this phenomenon. As a philosopher, Hick managed to catch the attention of philosophers of religion with his theory (and, of

\footnotetext{
A. Dastmalchian $(\bowtie)$

Autonomous Faculty of Protestant Theology, University of Geneva, Uni Bastions,

5 rue De-Candolle, $\mathrm{CH}-1211$ Geneva 4, Switzerland

e-mail: dastmal1@etu.unige.ch
}

A. Dastmalchian

Foundation for Interreligious and Intercultural Research and Dialogue, 10 rue Albert-Gos, CH-1206 Geneva, Switzerland 
course, with the philosophical arguments therein) even if non-philosophers have largely ignored him (see Kunin and Miles-Watson 2006; Pals 2006; Stausberg 2009).

Given that Hick focused (although not exclusively) on applying his theory to the religion with which he was most familiar, namely Christianity, and given the comparative lack of attention to non-Christian religions in English-language philosophy of religion, in this article I focus on applying Hick's theory of religion to Islam. Due to the complexity of this task, I can but offer an idea of how Hick's theory of religion will affect the general understanding a Muslim has of Islam. ${ }^{1}$ I will not be offering a thorough revision of Islamic theology, or of Quranic exegesis, or of Islamic law (and so forth). I instead intend to focus on how the Islamic religion has been traditionally understood by Muslims by presenting an account of Islam that covers some basic historical and doctrinal matters associated with the Islamic tradition. After presenting this picture, I will assess how it would change in the light of a Hickean understanding, specifically, in the light of two connected features of Hick's theory of religion: (1) the 'bottom-up' approach to religion and (2) belief in a trans-personal religious ultimate (that is, a religious ultimate that is beyond the concept of 'person').

By the 'traditional' Islamic narrative, I refer to the predominant narrative of the Islamic tradition through the ages, a teaching that gives rise to a 'traditional' or 'typical' Muslim self-understanding. As with any religious tradition, the Islamic religious tradition contains a variety of schools of thought, with each school containing differences that are regarded as significant from within. My use of the word 'traditional' is not intended to identify one form of Islam as opposed to another. My use of the word 'traditional' is instead intended to help identify (in lieu of a canonical creed such as the Nicene Creed of Christianity) ${ }^{2}$ the teaching that the majority of Muslims will both recognise and attest to.

The order of discussion in this article is to run as follows. First, I present a brief account of Hick's theory of religion and respond to a common objection to it, specifically, that it undermines religious confession. Second, I present an account of Islam that I believe will resonate with Muslims the world over. Third, I suggest how this narrative would change on a Hickean understanding and how some Muslim sensibilities might be accommodated.

\section{Hick's Theory of Religion}

Hick's theory of religion was developed over the course of some 20 years until its presentation in An Interpretation of Religion (1989). Hick continued to expound his theory after publication of this work, both through addressing the topic of religious diversity and through responding to numerous objections. Indeed, Hick's theory of religion raised so much discussion in Christian theology and the philosophy of religion that An Interpretation of Religion was reissued in 2004 with an additional

\footnotetext{
${ }^{1}$ We might casually refer to the understanding Muslims have of Islam as the Islamic 'self-understanding', although I prefer not to personify Islam in this way by attributing understanding to it. I will, however, refer to the understanding Muslims have of Islam as the traditional Islamic narrative.

${ }^{2}$ For classical (although non-canonical) statements of the Sunni and Shia creed, see, respectively, Tahawi 2007 and Ibn Babawayh 1999.
} 
introduction, which included Hick's responses to 15 types of 'serious and responsible' criticism (2004: xvii-xli).

According to Hick, the world's religious traditions are based on human responses to the religious ultimate, or the 'Real'. The Real itself is beyond categorisation although something can be done to describe what it is not (2004: xix-xxii, 239). There are also metaphorical, or mythical, accounts of the Real and it is these accounts that form the narrative of each religious tradition (2004: 247-248). For Hick, Jews understand the Real as Yahweh; Christians understand the Real as God the Father; Muslims understand the Real as Allah; and a whole host of other religious traditions understand the Real in their own characteristic ways. These different understandings are understandings of manifestations of the Real rather than of the Real as it is in itself. The different understandings of the Real are all false if taken literally but all true if taken metaphorically.

Hick's theory of religion, as encapsulated in the previous paragraph, arises from an attempt to consistently maintain that (1) there is a mind-independent reality (2004: 174-175) and (2) the universe is religiously ambiguous such that it is possible to rationally interpret it in both religious and non-religious ways. According to Hick (2004: 122-124, 154, 156-157), the religious ambiguity of the universe can be seen in the inconclusiveness of arguments for and against the existence of God. Religious ambiguity can also be seen in unusual events that lend themselves to being interpreted either as miracles or as natural phenomena. In cases of religious ambiguity, it is not that the relevant data fail to support any interpretation of it but rather the relevant data fail to fully determine any particular interpretation of it.

If (1) is rejected then, so to speak, 'anything goes' and the idea that there are a number of equally rational ways to interpret the universe - as expressed in (2) - does not especially give rise to a problem. If (1) is maintained and (2) is rejected, then a person could affirm that only one mode of interpreting the universe is rational. This affirmation could involve a rejection of all religious interpretations of the universe as being ungrounded in any form of mind-independent reality. Alternatively, rejecting religious ambiguity can also involve a rejection of all non-religious interpretations of the universe and all religious interpretations of the universe except for a person's own religious interpretation. To Hick this latter attitude seemed both arbitrary and arrogant (Hick 2004: 235, 2010: 26) and so he was left with the problem of explaining how multiple religious interpretations of the universe could all be rational. ${ }^{3}$ Various religious interpretations of the universe can all be rational, according to Hick, because none of them should be taken to be literal descriptions of the Real as it is in itself. Consider, for example, William Shakespeare's (1993) metaphor that all the world is a stage (As You Like It [ca.1600], Act 2, scene 7) and his metaphor that the world is an oyster (The Merry Wives of Windsor [ca.1600], Act 2, scene 2). Both these metaphors refer to the world but because we do not understand them literally we would not think that they are incompatible with each other. Furthermore, because the world is

\footnotetext{
${ }_{3}^{3}$ The charge that advocating a specific religious perspective is arbitrary and arrogant follows from Hick's contention that the universe is religiously ambiguous and that religious belief involves interpreting the universe in a religious way. Hick has also expressed this contention by saying that the best way to support religious belief is through appeal to religious experience. But to consider only one's own religious interpretation as valid is rather disingenuous to the point of being arbitrary. On the other hand, if one denies religious ambiguity in the universe then one is being closed minded to the point of arrogance.
} 
complex enough to have more than one interpretation neither would we be inclined to say that only one of Shakespeare's metaphors is correct.

We have seen how, according to Hick, different understandings of the Real, corresponding to different world religious traditions, can all be metaphorically true. We have also seen how this arises out of a claim about how different interpretations of the religiously ambiguous universe can all be rational. Clearly, Hick's theory of religion (expressed in the former claim) is not entailed by Hick's epistemology (expressed in the latter claim). Hick himself referred to his theory of religion as the pluralist hypothesis - a hypothesis that tries to make sense of the variety of religious experience without holding it to be all delusory (2004: 235). The reason I am not also referring to Hick's theory as the pluralist hypothesis is because I believe Hick's intention to contribute to the study of religion, as a general phenomenon, has not always been recognised. As Hick (2004: xiii) says of his An Interpretation of Religion, 'The book is intended to contribute to a project which no one person can hope to complete, namely the development of a field theory of religion from a religious point of view'. Hick also says, with appeal to Eliade (1958: xi),

There are many general interpretations of religion. These have usually been either naturalistic, treating religion as a purely human phenomenon or, if religious, have been developed within the confines of a particular confessional conviction which construes all other traditions in its own terms. The one type of theory that has seldom been attempted is a religious but not confessional interpretation of religion in its plurality of forms; and it is this that I shall be trying to offer here. (Hick 2004: 1)

Lack of recognition for Hick's broad theoretical aims can be seen in numerous objections that roughly state that because Hick's theory of religion explains religions in terms that they do not recognise, then the theory must be untenable. As Byrne (1982: 299) puts it, 'The assertion that all religions worship the one thing, though describing it differently, implies falsely that the language used to describe the object of worship is dispensable'. Byrne could perhaps be excused for his self-confessed 'naiveté' in thinking that Hick's theory of religion could be refuted 'with reference to simple and quick arguments' (1995: viii) because he responded to an early version of Hick's theory. But the objection can also be seen in the writing of others. Upjohn Light (2009: 468), for example, says of Hick's theory that 'A meta-position claiming to represent the world religions actually contradicts them all'. Upjohn Light suggests that Hick, through his theory, effectively says to religious believers 'I know better what you're doing than you know yourself'. Legenhausen (1999: 152) also expresses a dislike for Hick's theory of religion: 'The root of the failure of Hick's pluralism is that it makes religion into a purely human response to the divine, or the Ultimate Reality, while Islam teaches that religion is revealed'. Legenhausen also states,

Hick's religious pluralism is the advocacy of a forced doctrinal synthesis. It will not allow for ultimate differences in religious belief. No matter how strenuously the Hindu or Buddhist denies the personal nature of ultimate reality, and no matter how fervently the Christian asserts it, Hick would claim that there is no real conflict. Each merely expresses features of his or her own avenue to the Ultimate. This fails to do justice to the lived differences and conflicts among the 
adherents of the world's religions. While religious pluralism is advertised as a theology of tolerance, it turns out to be intolerant of serious religious differences. (Legenhausen 2006: para 42)

A similar sentiment is expressed by Plantinga, who comments on Hick's theory of religion with some incredulity:

I am to remain a Christian, to take part in Christian worship, to accept the splendid and powerful doctrines of traditional Christianity. However, I am also to take it that these doctrines are only mythologically true: they are literally false, although accepting them (i.e., accepting them as true, as literally true) puts or tends to put one into the right relation with the Real. And how can I possibly accept them, adopt that attitude toward them, if I think they are only mythologically true - that is, really false? (Plantinga 2000: 61)

Perhaps the above criticisms are simply unsympathetic to (as opposed to unaware of) Hick's project of explaining religion in non-confessional terms. However, if there is in fact a lack of recognition for the breadth of Hick's aims, then the above critics might do well to call to mind the distinction between explanatory and descriptive types of reductionism in the analysis of religion. According to Proudfoot (1985: 196198), a theory of religion must not describe its subject matter in terms alien to it but it may explain its subject matter using such terms. Consequently, a theory of religion must take seriously the self-understanding of religious believers but may explain their belief and activity in ways that they would not even recognise. Twiss (1990: 542545) makes use of this point with particular reference to Netland's (1986: 255-257) criticism of Hick. As Twiss notes, some would consider the lack of 'hermeneutical adequacy' of Hick's theory to count decisively against it. Reçber (2005: 5), in his own criticism of Hick, appears to concede the Proudfoot-Twiss point that Hick is not unreasonable to go beyond the self-understandings of religious believers in the process of constructing an explanatory theory.

This study does assume that there is some value to Hick's project of seeking an explanatory theory of religion. On this basis Islam will be taken as a case study and it will be argued that the Hickean understanding of the Islamic narrative can be reconciled with the traditional understanding. This is not to say that a Muslim would want to necessarily wholeheartedly adopt Hick's theory of religion. After all, as we see in Hosseini 2010; Legenhausen 2006, 2013; Reçber 2005; Shah-Kazemi 2013, there are a number of criticisms of Hick's theory of religion from a Muslim perspective that are independent of anything that could be concluded from this study. However, by reconciling the Hickean understanding of the Islamic narrative with the traditional understanding, I at least hope to have shown that if acceptance of Hick's theory is incompatible with acceptance of Islamic beliefs then it is not because of the way the traditional Islamic narrative is re-written. In other words, if a Muslim wants to reject Hick's theory of religion, then his arguments must be directed to something other than the effect of the theory on the traditional Islamic narrative. This point, I believe, helps for a better understanding of how Hick's theory of religion relates to Islam and, perhaps, to other religions also.

Also, as Muslims and other religious believers seek new audiences and seek to maintain existing ones, it might be that my discussion will help show the extent to 
which the language of Hick's theory of religion can be used to explain religious beliefs in a new way. As Williams (a former Archbishop of Canterbury) notes in the context of responding to revisionary claims about the origins of Christianity,

[...] all human language does adjust to historical change, even when trying to stay the same; as Cardinal Newman [1801-1890] observed, to say the same thing as your ancestors said, you may well need to say something apparently very different. (Williams 2012; cf. Newman 1846: 27)

Perhaps this is the same sentiment that caused Mutahhari (1920-1979), in the context of advocating a rejuvenation of Islamic jurisprudence, to insist that new ideas need not necessarily be feared:

The greatest enemy of the Qur'an is inflexibility and the maintaining of an outlook of a particular time and a particular era, just as the greatest obstacle for understanding nature was that in the past scholars thought understanding nature meant understanding that which was related from the likes of Aristotle and Plato. (Mutahhari 1991: 73)

Mutahhari's reference to nature is poignant given that Hick (2004: 377) also referred to nineteenth-century debates surrounding the evolution of life on earth to say that in due course his theory of religion may be seen to be less threatening to religious belief than it is at the moment. ${ }^{4}$

So, even though Hick's theory of religion uses rhetoric that is different from traditional Islamic rhetoric, this study will proceed on the basis that this need not necessarily be a reason for a Muslim to reject Hick's theory. One Muslim thinker who has embraced Hick's ideas is Soroush (2009) yet Soroush conducts his discussion in his own terms and on the basis of his engagement with a wide range of thinkers from the Islamic and Western traditions that Hick does not even mention. This study on the other hand consciously seeks to engage with Hick on his own terms. ${ }^{5}$ The scope of this study also differs from Aslan's (1998) exposition, and comparison, of the thought of Hick and Nasr on the plurality and diversity of religion. While some remarks are made by Aslan (1998: 182-186) on Hick's view of Islam as a valid world religion, these remarks do not constitute an application of Hick's ideas to the Islamic narrative. Moreover, as Aslan shows, the analytical thought of Hick and the perennialist thought of Nasr are so different that they do not produce a synthesis of ideas that might be used in this study.

In the next section I will present the traditional Islamic narrative. This will be followed by a section in which I modify the traditional narrative in accordance with Hick's theory of religion and argue that a traditional Muslim need not reject the theory given that the two narratives can be reconciled.

\footnotetext{
${ }^{4}$ For some idea of how religious belief can be maintained in the face of evolutionary theory, see Dawes 2007; Haught 2008; Miller 1999; Ruse 2001.

${ }^{5}$ For an overview of Soroush's view of religion, see Dahlén 2003; Rizvi 2012. Although Soroush (2009: 134) expresses approval of Hick's pluralism, he clarifies, in response to a question posed to him at the end of a 2010 lecture, that he does not approve of any attempt to demystify or naturalise religion. In his response Soroush mentions his respect for Hick but says that, as a student of Rumi, he cannot neglect the supernatural realm. Listen to Soroush 2010 from $1 \mathrm{~h} 48 \mathrm{~min}$.
} 


\section{The Traditional Islamic Narrative}

Arabia, in the middle of the first millennium of the Common Era, was a foul place and the land of ignorance. The idol-worshipping, carrion-eating, baby-sacrificing tribes of its population were at continuous war with each other. From this intellectual and cultural backwater arose an upright and trustworthy gentleman called Muhammad. As Razwy says,

Arabia was a pit of iniquity and the bastion of idolatry and polytheism, Muhammad himself was never contaminated by any vice or sin, and he never bowed before any idol. Even before he formally declared that he came to establish the Kingdom of Heaven on earth [i.e. Medina], ${ }^{6}$ his own conduct and character were a reflection of [the] Qur'an - the glorious. Even his critics have not been able to point out any divergence between his conduct and the precepts of [the] Qur'an at any time, before or after the Proclamation. (Razwy 1997: 35)

It was not until the age of 40, in the year $610 \mathrm{CE}$, that Muhammad was visited by the Angel Gabriel, who told him to read in the name of his Lord, the Most Noble creator of mankind. The meeting occurred in the mountain cave of Hira outside the Arabian trading town of Mecca, a cave that Muhammad used to frequent in order to meditate. The meetings continued and Muhammad was informed that God had chosen him to convey His final message to mankind. The message, which was to be completed over the course of 23 years, detailed a new way of life with both creedal and practical dimensions. Thus, the age of ignorance ended and the age of Islam was born.

The message from God was conveyed faithfully by Gabriel to Muhammad and faithfully by Muhammad to Arabia and beyond, beginning with an invitation to his family and ending with the unification of Arabia upon the new religion. Some special parts of the message had been designated for verbatim transcription so that they could be collected as a book. The Quran, Arabic for 'recital', is this book - the literal word of God to mankind as conveyed by his final messenger and prophet. ${ }^{7}$ The statements of the Quran are true and to be believed on the basis that they are statements from God, who has no needs and therefore no need to lie. The chief sign of God being the author of the Quran is the Quran's inimitability. How else, except through revelation, was an unlettered man from an ignorant land to produce such a masterpiece? Sir Sayyid Ahmad Khan (1817-1898) writes:

\footnotetext{
${ }^{6}$ 'Kingdom of Heaven on earth' seems to be a phrase that Razwy has borrowed from the Bible to refer to the ideal political state as presided over by Muhammad, that is, the city of Medina. 'The State of Medina was the physical apparatus of the first and the last Kingdom of Heaven on Earth' (1997: 87). 'The Kingdom of Heaven on Earth which Muhammad Mustafa had founded, had ceased, after his death, to be "heavenly", and had become an ersatz Greek or Persian government' (1997: 481).

${ }^{7}$ In Islamic terminology, a messenger (rasul) who is human (rather than angelic) is one who receives, through revelation, a new Scripture for propagation. Such messengers include Abraham, Moses, David, Jesus, and Muhammad, although others have also been acknowledged. A prophet (nabi), on the other hand, is anybody who has been appointed by God to teach and guide. The class of messengers, therefore, is included in the class of prophets. (See Bearman et al. 2013.) The Qur'an refers to Muhammad as the 'seal of the prophets' (33:40) and this is understood to mean that he was the final prophet and, therefore, the final messenger too.
} 
I [...] do not think it out of place to argue that a person who was born in a land full of sand and stones, who had become an orphan at a tender age, who had neither received training in a dār al 'ulūm (big madrasah [religious school]) nor heard the doctrines of Socrates, Hippocrates or Plato, nor sat at the feet of an ustād [teacher] nor enjoyed the company of wise men, philosophers or men of political and moral science, but who spent forty years of his life among uneducated and rude camel drivers, who for forty years had seen nobody but a people addicted to idolatry, internecine warfare and men and women who prided themselves on theft and fornication. Such a man, who all at once rose against all his own people and, albeit surrounded on four sides of idolatry, yet professed La ilāha [illa] Allāh [There is no god but God] - who not only said it but made all his people say it, who for centuries had worshipped Lāt and Manāt and 'Uzzá, who eradicated from his people all this bad behaviour and these immoral practices; who made them throw to the ground and break their idols and exalted the name and worship of God throughout the entire peninsula, the peninsula which, after Abraham and Ishmael, had been sullied by a thousand act[s] of impurity. Who then restored to it its original purity and the great religion of Abraham? Who, I ask, after forty years put light in man's heart, the light which has illumined not only the Arab peninsula but the whole world? (Troll 1978: 323-324)

The Quran not only confirmed the truth of Muhammad's mission as being by divine decree, but confirmed the missions of all the previous prophets, from Adam through Abraham, Moses, and Jesus. Before Muhammad, mankind was not sufficiently developed to receive the final perfected religion and could only bear it in simple and incomplete form. But the religion that Muhammad brought was complete and Muhammad is, therefore, the final messenger of God.

Much in the Islamic religion is familiar to Jews and Christians in particular. Talk of an almighty God, revelation, prophets, judgement, heaven, hell, angels, and devils is a part of the vocabulary of the three religions. But the Islamic tradition sees itself as the recipient of an uncorrupted religion of pure and unadulterated monotheism:

The Jews call Uzair a son of God and the Christians call Christ the son of God. That is a saying from their mouths; they but imitate what the unbelievers of old used to say. God fights against them: how they are deluded away from the truth! They take their priests and their anchorites to be their lords instead of God and (also) Christ the son of Mary; yet they were commanded to worship but one God: there is no god but He. Glory to Him from the partners they associate (with Him). (Quran, 9:30-31)

Islam, very much like Judaism but not very much like Christianity, contains a law dealing with both social interactions and private matters of worship that is to be followed in obedience to God and for the material and spiritual benefit of ourselves in this life, as well as for the benefit to ourselves in the afterlife. The law is derived from the Quran and tradition (Sunnah) of Muhammad, which together can be called 'scripture'. For Sunni Muslims, the companions of Muhammad and the two generations of Muslims after them are also sources of authority. For Shia Muslims this is 
not the case; instead select members of Muhammad's family and descendents are authoritative.

Muslims throughout the Muslim nation (ummah) will, I believe, recognise and attest to the foregoing account of the Islamic narrative. ${ }^{8}$ However, what would the traditional Islamic narrative look like according to Hick's theory of religion? In the next section I seek to answer this question by suggesting how key parts of the Islamic narrative would be written in Hickean terms. I aim to show that accepting Hick's theory of religion does not mean changing the narrative beyond recognition or in ways that a traditional Muslim could never accept.

\section{Modifications to the Traditional Islamic Narrative}

Borrowing from Hick (2005: 7), we can say that Muslims tend to think of Islam in a 'top-down' way. The top-down perspective can be seen to be operating in the traditional Islamic narrative in the idea that God reveals himself to Muhammad such that Muhammad is a passive recipient of the revealed message. This top-down perspective is reinforced by the Quran with its use of the word tanzil when referring to revelation, a word that connotes sending down, and not just wahy, a word that does not carry the connotation of sending down. ${ }^{9}$

In contrast to the top-down approach to religion, Hick's theory of religion is developed from (and hence requires) a 'bottom-up' approach. This approach is encapsulated in the sub-title of Hick's major work on religious diversity, An Interpretation of Religion (2004 [1989]). The subtitle of this work is Human Responses to the Transcendent. Hick believes that religions - contrary to the understanding their adherents might have - are the result of individual and community responses to the transcendent and ultimate reality, that is, the Real (2004: 1, 10-11, 153-158). As Hick (2005: 7) puts it, the bottom-up approach to religion starts with the observable realities of human life and asks what they imply. We might understand the bottom-up approach as an approach that is more receptive of explanatory naturalism than the top-down approach. In other words, in the bottom-up approach supernatural entities and processes are not immediately invoked in order to explain religious phenomena. ${ }^{10}$

Approaching Islam 'from-the-bottom-up' changes the narrative of the previous section. The history regarding the condition of pre-Islamic Arabia and of Muhammad's impeccable conduct need not be revised when rewriting the Islamic narrative. Neither do the historical beliefs regarding dates and places need to change. What changes is the account of how Muhammad came into contact with God or, in Hickean terms, the Real.

A Hickean version of the Islamic narrative might start by noting Muhammad's strong sense of morality and the distress he would have felt from witnessing the moral corruption of his society. This, together with his contemplative habit and the

\footnotetext{
${ }^{8}$ For other short accounts of the Islamic narrative, see Akhtar 1990: 3-6, 2008: 18-35; Shepard 2009: 6-9.

9 The n-z-l root occurs 293 times in the Quran, in 12 derived forms, including 15 times as tanzil; the w-h-y root occurs 78 times in the Quran, in 2 derived forms, including 6 times as wahy (Dukes 2011). Madigan 2013 discusses both the concept of tanzil and the concept of wahy.

${ }^{10}$ For an examination of religious and naturalist explanations, see Dawes 2009.
} 
proximity he would have to the natural world in those days, led to the most profound mystical experiences imaginable. These mystical experiences compelled Muhammad to reform Arabia in line with universal moral principles, as can be seen in the appeal of an early Muslim, Jafar ibn Abi Talib, to the Negus of Abyssinia.

O King, we were an uncivilized people, worshipping idols, eating corpses, committing abominations, breaking natural ties, treating guests badly, and our strong devoured our weak. Thus we were until God sent us an apostle whose lineage, truth, trustworthiness, and clemency we know. He summoned us to acknowledge God's unity and to worship him and to renounce the stones and images which we and our fathers formerly worshipped. He commanded us to speak the truth, be faithful to our engagements, mindful of the ties of kinship and of kindly hospitality, and to refrain from crimes and bloodshed. He forbade us from committing abominations and from speaking lies, and from devouring the property of orphans, and from vilifying just women. He commanded us to worship God alone and to not associate anything with Him, and he gave us orders about prayer, almsgiving, and fasting [...]. (Guillaume 1955: 151-152, with grammatical mistakes edited)

The bottom-up approach to Islam, as required by Hick's theory of religion, allows us to understand the context in which Muhammad's mystical experiences occurred. This contextualisation in turn allows us to understand why Islam is called the religion of human nature (din al-fitrah) (see Quran 30:30; Mohamed 1996). It is, perhaps, because Muhammad's experiences were a reaction to the inhumane moral corruption of his day that the concept of an uncorrupted human nature is so important to Islam.

On a Hickean understanding, Muhammad's experiences were made possible by his openness to the Real and the moral corruption of his society was made possible by the opposite inclination. In alternative Hickean terms, we can say Muhammad was reality-centred whereas the majority of his society was self-centred. It would not be incorrect to say, with the proponents of the top-down approach, that God caused Muhammad's experiences; it is just that the bottom-up approach to religion, Hick would argue, seems to give us a clearer picture of the experiences that prompted Muhammad to establish a new religion.

So, on a Hickean account, Muhammad understood his contact with the Real - not incorrectly - in terms of revelation from God delivered by the Angel Gabriel. According to Hick (2010: 119) 'when a human being is exceptionally open to the divine presence, he or she has a vivid awareness of God, which is then called revelation'. Muhammad's understanding of his contact with the Real follows from his awareness of Judaism and Christianity and perhaps from the general religious milieu of fifth-century Arabia. ${ }^{11}$ But Hick's theory of religion does not restrict revelation, that is, openness to the Real. On a Hickean account it is in principle possible for anybody to be open to the Real and therefore for anybody to experience receiving revelation. It is difficult, therefore, to give a Hickean basis to the claim that Muhammad was the final messenger and prophet of God. If no such basis can be

\footnotetext{
${ }^{11}$ The exact cultural and religious environment of the Arabia of Muhammad's day has been the subject of some discussion. Cf. Crone 1987; Hoyland 2001; Peters 1994; Serjeant 1990.
} 
found then it would seem that the traditional Islamic narrative and the Hickean version of it really do conflict.

But just because potentially anybody can be open to the Real and to therefore construing her or his experience in terms of receiving revelation, it does not mean that anybody after Muhammad has (or will). While Hick's theory of religion does not corroborate Muhammad's claim that he was the final messenger and prophet of God, it does not deny the claim. Muslims are therefore free to maintain this part of the traditional narrative. It could be, for example, that Muhammad predicted (rather than prophesised) the final nature of his mission from witnessing the decline of humanity. After all, who nowadays could claim to be so uncorrupted from birth by modern society and the built environment that he could have such profound mission-inducing responses to the Real? Perhaps Muhammad could tell that his experiences were rare enough for his day let alone for the times that were to come after him.

The bottom-up approach gives an understanding of Islam in terms of Muhammad's response to his place-time. It would therefore seem right, in line with this approach, that were a defence of Islamic beliefs and practices to be constructed, emphasis would be placed on arguing that Muhammad had an astounding character that allowed his response to the Real and that therefore made his teaching worth following. Furthermore, emphasis would be placed on the advantage of adopting Muhammad's teaching. This apologetic strategy can be contrasted with the strategy adopted by the topdown approach to Islam, which places emphasis on proving the existence of God, His intentions for mankind, and that the Quran is the exact record of a genuine revelation from God. This is not to say that the top-down approach to Islam does not argue that Muhammad had an impeccable character or that his teaching is beneficial. It is rather the case that adopting a bottom-up approach to Islam requires a shift of emphasis, which affects the way Islam is presented and defended.

Hick claims that his theory of religion is not alien to the religious traditions and he recounts some of the evidences for this view. With regard to Islam, Hick (2004: 50, $233,274)$ appeals to the great Sufi poet, Jalal al-Din Rumi (1207-1273), and to the Andalusian mystic, Ibn Arabi (1165-1240). These figures teach of a more complex understanding of Islam that goes beyond the basic picture outlined in the previous section. Important in their teachings is a trans-personal conception of God (DeLamotte 1980: 13; Izutsu 1983: 23; Khosla 1987: 21-25; Rizvi 2008: 368369). ${ }^{12}$ Such a conception of God, also popular among Muslim theologians (Legenhausen 1986), leads naturally to a bottom-up approach to Islam, which is the approach required for adoption of Hick's theory of religion. This is because if God is not literally thought of as a person, albeit of infinite perfection, it will not be thought that He communicated with Muhammad as human people communicate with each other (albeit via an angel) whereby ideas are conveyed by means of language. A trans-personal conception of God calls out for a bottom-up approach to Islam for if God did not literally intend for Muhammad to convey a message, the Islamic

\footnotetext{
12 'Trans-personal' is not a commonly used term and it may seem more appropriate to ascribe belief in an impersonal God to Ibn Arabi, Rumi, and Muslim theologians in general. However, in the light of Hick's (2004: xx-xxii, 252-296) discussions, this term no longer seems to suggest the opposite of 'personal'. I am confident that Ibn Arabi, Rumi, and Muslim theologians in general, would not want to suggest that either 'personal' or 'impersonal' fully captures what it is to be God.
} 
narrative (allegory withstanding) must be understood in a different way, which means a bottom-up rather than a top-down way.

Explaining Islamic beliefs and practices in Hickean terms is sure to face challenges. A challenge of the bottom-up approach to Islam would be to explain why scripture should not always be taken at face value, why we should understand anything in non-scriptural terms, and why the traditional narrative is open to being told in a different way. Another issue would be explaining why the personal attributes of God mentioned in scripture should not be understood to mean that God is personal. This would in turn involve giving a new account of such things as petitionary prayer, which would have to mean something different to a petition of an all-hearing and all-powerful being to bring about a desired state of affairs. Yet a further issue would be to explain why the spirit of the Islamic law should be followed and not primarily its letter. So, for example, skin-to-skin contact in the form of a handshake between unrelated members of the opposite sex might be overlooked as a harmless greeting; and changing the congregational day for Muslims in the West from Friday to Sunday would not be seen as sacrilegious.

Existing discussions in the Islamic tradition, that is, from contexts not relating to Hick's theory of religion, will no doubt help inform responses to the challenges mentioned in the previous paragraph. My aim in this study has been to focus only upon the traditional Islamic narrative and to view how it changes in the light of a Hickean understanding of religion. I will therefore not be pursuing the specific issues raised in the previous paragraph any further despite their importance.

\section{Conclusion}

In this study I have been mindful to consider Hick's theory of religion in the light of its broad explanatory aims. I have been unpersuaded, therefore, by claims that Hick is unfaithful to the understandings religious believers have of their own religions. On this basis I have examined the traditional Islamic narrative, or what might be termed the typical Muslim self-understanding. The aim of this examination was to ascertain whether Hick's theory of religion does indeed display an incompatibility with Islamic belief. My assessment is that if the theory is incompatible with Islamic belief, then this incompatibility does not manifest itself at the level of belief in the narrative. The significance of this conclusion stems from it being widely held that Hick's theory of religion is in obvious error for seeking to explain the variety of religion in terms alien to the religions.

Although I have argued that the Hickean rendering of the Islamic narrative can be reconciled with the traditional narrative I do not mean to suggest by this that the traditional narrative should be henceforth discarded. Neither do I claim that a Muslim will not have other reasons (apart from incompatibility with self-understanding) to reject Hick's theory of religion. I do suggest, however, that a non-reactionary view of Hick's theory of religion will be able to identify the advantages and disadvantages of the theory. One advantage could be the naturalist presumption of Hick's theory, as expressed in the bottom-up approach to religion, which will allow religious believers to more effectively communicate with non-believers. In any case, I hope that my 
discussion will lead to a deeper understanding of Hick's theory of religion and that which unites the religions of the world. ${ }^{13}$

\section{References}

Akhtar, S. (1990). A faith for all seasons: Islam and the challenge of the modern world. Chicago: Ivan R. Dee.

Akhtar, S. (2008). The Quran and the secular mind: A philosophy of Islam. New York: Routledge, London. Aslan, A. (1998). Religious pluralism in Christian and Islamic philosophy: the thought of John Hick and Seyyed Hossein Nasr. Richmond: Curzon Press.

Bearman, P., Bianquis, Th., Bosworth, C. E., van Donzel, E., and Heinrichs, W. P. (Eds.) (2013). 'Rasul'. In Encyclopaedia of Islam (Second Edition). Brill Online. http://referenceworks.brillonline.com/entries/ encyclopaedia-of-islam-2/rasul-COM_0911. Last accessed: 25 February 2013.

Byrne, P. (1982). John Hick's philosophy of world religions. Scottish Journal of Theology, 35(4), $289-301$.

Byrne, P. (1995). Prolegomena to religious pluralism: Reference and realism in religion. Basingstoke: Macmillan.

Crone, P. (1987). Meccan trade and the rise of Islam. Princeton: Princeton University Press.

Dahlén, A. P. (2003). Islamic law, epistemology and modernity: Legal philosophy in contemporary Iran (Revth ed.). New York \& London: Routledge.

Dawes, G. W. (2007). Can a Darwinian be a Christian? Religion Compass, 1(6), 711-724. doi:10.1111/ j.1749-8171.2007.00050.x. Last accessed 25 February 2013.

Dawes, G. W. (2009). Theism and explanation. London: Routledge.

DeLamotte, R. C. (1980). Jalaluddin Rumi: Songbird of Sufism. Lanham (MD): University of America Press.

Dennett, D. C. (2006). Breaking the spell: Religion as a natural phenomenon. New York: Viking.

Dukes, K. (2011). The Quranic Arabic Corpus. http://corpus.quran.com. Last accessed: 25 February 2013.

Durkheim, É. (1915). The elementary forms of the religious life: A study in religious sociology, Swain, Joseph Ward (trans.). London: George Allen \& Unwin.

Eliade, M. (1958). Patterns in comparative religion, Sheed, Rosemary (trans.). New York: New American Library.

Guillaume, A. (1955). The life of Muhammad: A translation of Ishaq's Sirat Rasul Allah. London, New York, Toronto: Oxford University Press.

Haught, J. F. (2008). God after Darwin: A theology of evolution. Boulder (Colorado) \& London: Westview.

Hick, J. (1989). An interpretation of religion: Human responses to the transcendent. Houndmills and London: Macmillan (Second edition: 2004).

Hick, J. (2004). An interpretation of religion: Human responses to the transcendent (2nd ed.). Houndmills (Hants.) and New York (NY): Palgrave Macmillan (Original publication: 1989).

Hick, J. (2005). The next step beyond dialogue. In P. F. Knitter (Ed.), The myth of religious superiority: Multifaith explorations of religious pluralism (pp. 3-12). Maryknoll, New York: Orbis Books.

Hick, J. (2010). Dialogues in the philosophy of religion (2nd ed.). Houndmills (Hants.) \& New York: Palgrave Macmillan (Pages 25-36 originally published as 'The Epistemological Challenge of Religious Pluralism', in Faith and Philosophy, 1997, vol. 14, issue 3, pages 277-286. Pages 115141 originally published as 'A Pluralist View', in Four Views on Salvation in a Pluralistic World, ed. Dennis Ockholm \& Timothy R. Phillips (Grand Rapids: Zondervan, 1995), 29-59).

Hosseini, S. H. (2010). Religious pluralism and pluralistic religion: John Hick's epistemological foundation of religious pluralism and an explanation of islamic epistemology toward diversity of unique religion. The Pluralist, 5(1).

Hoyland, R. G. (2001). Arabia and the Arabs: From the bronze age to the coming of Islam. London \& New York: Routledge.

Ibn Babawayh, M. A. (1999). A Shi'ite Creed, Fyzee, Asaf A. A. (trans.), 3rd edition. Tehran: WOFIS.

\footnotetext{
${ }^{13}$ I would like to express my gratitude to the editors and their anonymous reviewers for providing me with both the opportunity and the detailed feedback for revising the article upon which this present study has been based.
} 
Izutsu, T. (1983). Sufism and Taoism: A comparative study of key philosophical concepts. Berkeley, Los Angeles, and London: University of California Press.

Khosla, K. (1987). The Sufism of Rumi. Longmead (Dorset): Element Books.

Kunin, S. D., \& Miles-Watson, J. (2006). Theories of religion: A reader. New Brunswick \& Edinburgh: Rutgers University Press \& Edinburgh University Press.

Legenhausen, G. (1986). Is God a person? Religious Studies, 22, 307-323.

Legenhausen, M. (1999). Islam and religious pluralism. London: Al-Hoda.

Legenhausen, M. (2006). A Muslim's proposal: Non-reductive religious pluralism, http:/www.uibk.ac.at/theol/ leseraum/texte/626.html. Last accessed: December 2007. (An expanded version of ‘A Muslim's Non-Reductive Religious Pluralism', in Islam and Global Dialogue, ed. Roger Boase (Aldershot: Ashgate, 2005), 51-73.)

Legenhausen, M. (2013). Nonreductive pluralism and religious dialogue. In M. H. Khalil (Ed.), Between heaven and hell: Islam, salvation, and the fate of others. New York: Oxford University Press.

Madigan, D. A. (2013). Revelation and inspiration. In J. D. McAuliffe (ed.) Encyclopaedia of the Qur'an. Brill Online. http://referenceworks.brillonline.com/entries/encyclopaedia-of-the-quran/revelation-andinspiration-COM_00174. Last accessed: 25 February 2013.

Miller, K. R. (1999). Finding Darwin's God: A scientist's search for common ground between god and evolution. New York: Cliff Street Books.

Mohamed, Y. (1996). Fitrah: The Islamic concept of human nature. London: Ta-Ha.

Mutahhari, M. (1991). [1370 AH (solar)]. Khatm-e Nubuvvat (The Seal of Prophethood), 6th edition. Sadra.

Netland, H. A. (1986). Professor Hick on religious pluralism. Religious Studies, 22(2), 249-261.

Newman, J. H. (1846). An essay on the development of Christian doctrine (2nd ed.). London: James Toovey. Pals, D. L. (2006). Eight theories of religion. New York \& Oxford: Oxford University Press.

Peters, F. E. (1994). Muhammad and the origins of Islam. Albany: State University of New York Press.

Plantinga, A. (2000). Warranted Christian belief. Oxford and New York: Oxford University Press.

Proudfoot, W. (1985). Religious experience. London: University of California Press.

Razwy, S. A. A. (1997). A restatement of the history of Islam and Muslims, CE 570 to 661 . Stanmore (London): World Federation of KSI Muslim Communities.

Reçber, M. S. (2005). Hick, the real and Al-Haqq. Islam and Christian-Muslim Relations, 16(1), 3-10.

Rizvi, S. H. (2008). Ibn 'Arabi. In A. Rippin (Ed.), The Islamic world. Abingdon (Oxon.): Routledge.

Rizvi, S. H. (2012). Oneself as the saved other? The ethics and soteriology of difference in two Muslim thinkers. In M. H. Khalil (Ed.), Between heaven and hell: Islam, salvation, and the fate of others (pp. 180-203). New York: Oxford University Press.

Ruse, M. (2001). Can a Darwinian be a christian? The relationship between science and religion. Cambridge: Cambridge University Press.

Serjeant, R. B. (1990). Meccan trade and the rise of Islam: misconceptions and flawed polemics. Journal of the American Oriental Society, 110(3), 472-486.

Shah-Kazemi, R. (2013). Beyond polemics and pluralism: The universal message of the Qur'an. In M. H. Khalil (Ed.), Between heaven and hell: Islam, salvation, and the fate of others. New York: Oxford University Press.

Shakespeare, W. (1993). The complete works of William Shakespeare. Created by Jeremy Hylton. Operated by The Tech. http://shakespeare.mit.edu. Last accessed: 1 March 2013.

Shepard, W. (2009). Introducing Islam. Abingdon (Oxon.) \& New York: Routledge.

Soroush, A. (2009). The expansion of prophetic experience: Essays on historicity, contingency and plurality in religion, Mobasser, Nilou (trans.). Leiden: Brill.

Soroush, A. (2010). Thoughts on the eternal and contextual in the Qur'anic message. Shia Ithna'ashari Community of Middlesex, Harrow, Middlesex, UK; 15 October 2010. http://www.sicm.org.uk/zina new/index.php?p=AbdolKareem\%20Soroush. Last accessed: 1 March 2013.

Stausberg, M. (Ed.). (2009). Contemporary theories of religion: A critical companion. Abingdon \& New York: Routledge.

Tahawi, A. M. (2007). The creed of Imam al-Tahawi: Al-Aqidah al-Tahawiyyah, Yusuf, Hamza (trans.). Zaytuna Institute.

Troll, C. W. (1978). Sayyid Ahmad Khan: A reinterpretation of Muslim theology. New Delhi: Vikas Publishing House.

Twiss, S. B. (1990). The philosophy of religious pluralism: a critical appraisal of Hick and his critics. The Journal of Religion, 70(4), 533.

Upjohn Light, A. (2009). Harris, Hick, and the Demise of the pluralist hypothesis. Journal of Ecumenical Studies, 44(3), 467-470.

Williams, R. (2012). From Christian Beginnings by Geza Vermes - Review, The Guardian, 11 July 2012, London. http://www.guardian.co.uk/books/2012/jul/11/christian-beginnings-geza-vermes-review. Last accessed: 21 February 2013. 